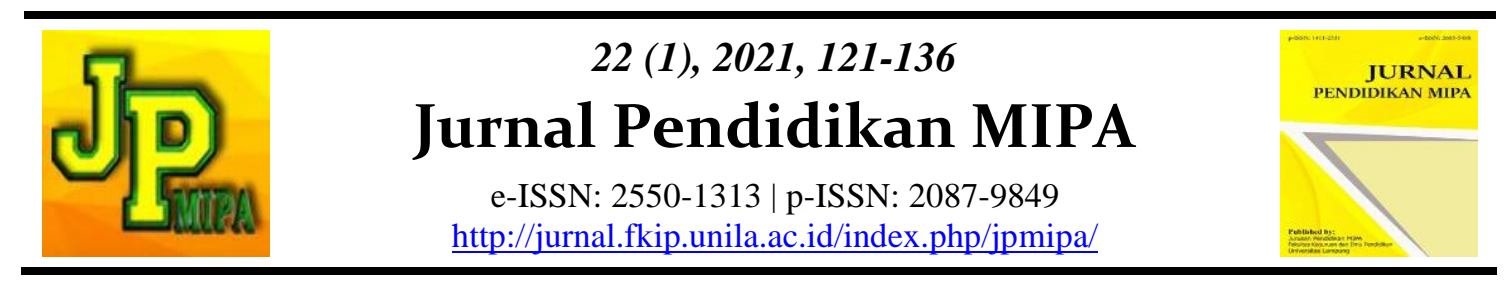

\title{
Development of Worksheet of Conceptual Change to Reduce Misconceptions about VSEPR and Hybridization for Low Imagination Students
}

\author{
Sri Herli Indriyani, Suyono, Utiya Azizah \\ Postgraduate School of Science Education, Universitas Negeri Surabaya, Indonesia
}

\begin{abstract}
Efforts to reduce the misconceptions of students with low imagination ability on the VSEPR concept and hybridization are urgent to do. This study aims to produce a worksheet of conceptual change (WCC) that is suitable for reducing VSEPR misconceptions and hybridization in students with low imagination ability. This development research followed the 4-D model stages (Define, Design, Develop, and Disseminate) and only reached the third stage. The research data were analyzed descriptively. The results of the study: (1) The two WCCs (VSEPR concept and hybridization concept) that were developed were declared to meet the requirements of construct and content validity with the majority of the highest mode values being 5 (very valid) and there were no conceptual errors; (2) The two WCCs developed were found to be practical to use; the majority (above $85 \%$ ) of user students gave a positive assessment of the 14 practicality indicators, and (3) Both WCCs were declared effective because the majority of students (90\%, respectively) had successfully changed their conceptions to understand concepts. Thus, it can be concluded that the two WCCs developed are suitable for reducing VSEPR misconceptions and hybridization in students with low imagination abilities.
\end{abstract}

Keywords: development, worksheet of conceptual change, low imagination.

Abstrak: Upaya mereduksi miskonsepsi siswa berkemampuan imajinasi rendah pada konsep VSEPR dan hibridisasi urgen untuk dilakukan. Penelitian ini bertujuan untuk menghasilkan lembar kerja perubahan konseptual (WCC) yang layak digunakan untuk mereduksi miskonsepsi VSEPR dan hibridisasi pada siswa berkemampuan imajinasi rendah. Penelitian pengembangan ini mengikuti tahapan 4-D model (Define, Design, Develop, dan Disseminate) dan baru sampai tahap ketiga. Data hasil penelitian dianalisis secara deskriptif. Hasil penelitian: (1) Dua WCC (konsep VSEPR dan konsep hibridisasi) yang dikembangkan dinyatakan memenuhi syarat validitas konstruk dan isi dengan mayoritas nilai modus tertinggi 5 (sangat valid) dan tidak terdapat kesalahan konsep; (2) Dua WCC yang dikembangkan dinyatakan praktis digunakan; mayoritas (di atas 85\%) siswa pengguna memberikan penilain positif terhadap 14 indikator kepraktisan, dan (3) Kedua WCC dinyatakan efektif karena mayoritas siswa (90\%, masingmasing) berhasil diubah konsepsinya menjadi paham konsep. Dengan demikian dapat disimpulkan bahwa kedua WCC yang dikembangkan layak digunakan untuk mereduksi miskonsepsi VSEPR dan hibridisasi pada siswa berkemampuan imajinasi rendah.

Kata kunci: pengembangan, lembar kerja perubahan konseptual, imajinasi rendah.

\section{- INTRODUCTION}

Researchers in science education are interested in the topic of misconceptions, characteristics of students with misconceptions, and the needs of students with misconceptions to change their conception status into correct concepts according to

Sri Herli Indriyani et al.

Corresponding Email: sriherliindriyani@gmail.com
DOI: http://dx.doi.org/10.23960/jpmipa/v22i1.pp121-136

Received: 20 May 2021

Accepted: 23 June 2021 
scientists. This is in accordance with the opinion of Eymur \& Omer (2016) that researchers in science education are interested in problems, (i) changing students' prior knowledge that is not in accordance with scientifically accepted conceptions, (ii) reducing students' misconceptions, and (iii) achieving meaningful learning that involves active students in the learning process. Misconception is a concept that is not in accordance with scientific understanding or understanding accepted by experts in certain fields (Suparno, 2013).

Previous researchers explained several factors for the occurrence of misconceptions. Ozmen (2004) indicated that misconceptions arise as a result of personal experience, traditional language instructions, mismatch between student and teacher knowledge, abstract nature of scientific concepts, and incorrect concepts in textbooks. Chiu (2005) revealed that the factors that occur in students' misconceptions can be in the form of internal students, textbooks, learning processes, learning media, and language. Internal factors can be interpreted as factors that come from within students according to individual characteristics. Individual characteristics include learning styles, mental models, and levels of cognitive conflict that can influence scientific conceptions. This research is limited to individual characteristics including students' mental models.

Laliyo (2011) explains that mental models represent ideas in an individual's mind that are used to describe and explain phenomena. Mental models are built by the characteristics of perception, imagination, and understanding of discourse. this research is limited to the students' imagination ability. Meyer (2013) defines imagination as the ability and process of forming a mental model or image of something that cannot be detected with common sense, the ability to solve problems in a non-linear way, and the ability to create new images from past experiences either in the form of pictures or images. oral. Yayla \& Gulseda (2011) also explained that students' imagination can determine conceptual change in knowledge and is effective in expressing misconceptions. This indicates that the imagination that is built properly can affect the formation of correct concepts or concepts that are scientifically acceptable, so as to reduce the burden of students' misconceptions.

Facts in the field reveal that students have a lot of misinformation and many have difficulties and misconceptions about the concept of VSEPR and hybridization (Uyulgan, Nalan, \& Senol, 2014; Uyulgan \& Nalan, 2016; Perez et al., 2017). The concepts of VSEPR and hybridization are abstract concepts so that students have difficulty understanding concepts at the sub-microscopic level and allow misconceptions to occur. This is in accordance with the opinion of Yayla \& Gulseda (2011) that chemical concepts that are abstract and have a sub-microscopic level cause students to have difficulty understanding and connecting new concepts with concepts in cognitive structures, thus allowing misconceptions to occur.

Perez et al. (2017) reported that most general chemistry textbooks explain molecular geometry through VSEPR theory, usually drawing the shape of a molecule with a symbol image made with lines and dots to represent the distribution of electron pairs around the central atom. Uyulgan \& Nalan (2016) emphasized that molecules should be drawn in three dimensions. According to Wang \& Barrow (2013) the perception of molecules in three dimensions can help improve the concept of understanding in chemical reactions and molecular structures (Uyulgan \& Nalan, 2016).

Tasker \& Rebecca (2006) mostly teach chemistry at the macroscopic and symbolic level, and students experience many misconceptions in chemistry due to the 
inability to visualize structures and processes at the sub-microscopic level. That is, it cannot change one of the attributes of students' mental models, in other words, students' imaginations are low. Verawahyuni (2014) reported that the higher the students' imagination, the lower the level of students' misconceptions. Whereas the concept of VSEPR and hybridization is abstract and requires visual-spatial intelligence to have good imagination skills at the sub-microscopic level process.

Hegarty (2012) explained that spatial ability is important in understanding chemistry, especially the concept of VSEPR and hybridization. Sabekti, Widarti, \& Mahmudi (2014) emphasized that molecular shape is a concept that requires high imagination. This is one of the biggest challenges in the world of education, so efforts are needed as a service for students with low imagination which is expected to reduce the burden of student misconceptions.

Service students with low imagination can be assisted with audio-visual. Audiovisual media can visualize structures and processes at the sub-microscopic level. Audiovisual media is a source of interesting, effective learning, and avoids or reinforces misconceptions. This is supported by Tasker \& Rebecca (2006) that the audiovisual information processing model developed by Johnstone and Mayer informs teaching practice with animation affecting the development of students' mental models. The results of the research by Tindall-Ford \& Sweller (2006) reported that grade 8 students accompanied by audio or visual could improve students' understanding of concepts in the learning process (Abdullah \& Johari, 2015).

Students' imagination has an important role in changing students' conceptions towards a better direction and having concepts that are scientifically appropriate, if given the right strategies in learning. The strategy used must be integrated with the students' imagination. Efforts to change and reduce / reduce the burden of students' misconceptions require immediate action. Misconceptions can be eliminated by using a conceptual change strategy. This is supported by Agiande, James, Albert, \& Danbiyu (2015) that conceptual change is seen as a series of teaching strategies used to change the student's wrong point of view into a point of view that is in accordance with scientists as a learning process.

Chemistry education literature reports that learning using conceptual change strategies is better in forming the concept of chemical bonds scientifically compared to using traditional strategies (Eymur \& Omer, 2016). The learning process uses effective conceptual change strategies to overcome and reduce the burden of misconceptions into correct concepts according to scientific concepts. Suyono, Masriyah, \& Muchlis (2016) have succeeded in developing the simplest conceptual change strategy consisting of four stages, namely: (1) validation or clarification of wrong conceptions, (2) creating cognitive conflict conditions in individuals, (3) providing assistance for the occurrence of equilibration, and (4) reconstruction of individual understanding. The conceptual change strategy is administered in the form of a worksheet called the worksheet of conceptual change (WCC).

WCC as a service for students with low imagination needs to be developed for supporting teaching materials in remedial learning for students who have a low imagination index with misconception status. The provision of WCC aims to reduce or reduce the burden of VSEPR concept misconceptions and hybridization in students with low imagination abilities. The development of WCC has requirements that include: (i) validity, (ii) practicality, and (iii) effectiveness (Plomp \& Nieveen, 2010). 
The researchers found that not all individuals successfully changed their misconceptions after being treated with WCC. The results of Majid's research (2018) report that at the end of the process of changing the conception, $20 \%$ of students still have a misconception status. It is necessary to find the factors causing the failure in terms of the process of conceptual change and it is necessary to describe what changes in the conception of individuals with low imagination abilities are when undergoing therapy to correct their misconceptions.

The research objective is to describe the feasibility of the worksheet of conceptual change on the VSEPR concept and hybridization for students with low imagination. The research was carried out in stages, namely: (1) the stage of determining the target students (students who have a low imagination index with a misconception status) required two instruments which include, namely a test for detecting students' imagination abilities that have been developed (appropriate) by Verawahyuni (2014) and a test VSEPR conception and hybridization that have met the consistency and relevance requirements as a concept understanding test instrument sheet to identify students' conception status; and (2) the stage of giving WCC treatment to target students to reduce VSEPR misconceptions and hybridization to students with low imagination abilities.

\section{- METHOD}

\section{Research Design}

This research is a type of research and development or Research and Development (R\&D). WCC development requires a careful development plan to produce quality products. WCC development refers to the 4-D (four-D) development model which consists of 4 stages, namely: Define, Design, Develop, and Disseminate (Thiagarajan et al., 1974). This research has only reached the development stage.

\section{Sample}

The subjects of this study included three expert lecturers in the field of chemistry, State University of Surabaya and students of class X MIPA at SMAN 1 Sumenep. This research was conducted at the Master of Science Education Study Program, Postgraduate, State University of Surabaya Even Semester 2020/2021 and SMAN 1 Sumenep in the 2020/2021 academic year (after receiving VSEPR and hybridization materials).

\section{Instruments}

Data collection techniques and research instruments are used to obtain materials that are relevant, accurate, and can be used appropriately according to the research objectives. Data collection techniques and instruments used in this study are shown in Table 1.

Table 1. Data Collection Techniques and Research Instruments

\begin{tabular}{llll}
\hline No & \multicolumn{1}{c}{ Variable } & Data Collection Techniques & Instruments \\
\hline 1 & Validity of $W C C:$ & Validation with closed & Validation sheet \\
& a. Construct & $\begin{array}{l}\text { assessment } \\
\text { Validation with open and } \\
\text { b. Content }\end{array}$ & Validation sheet \\
& & closed assessment & \\
\hline
\end{tabular}




\begin{tabular}{|c|c|c|c|}
\hline No & Variable & Data Collection Techniques & Instruments \\
\hline 2 & $\begin{array}{l}\text { Practicality of } \\
W C C\end{array}$ & Questionnaire & Students respons sheet \\
\hline \multirow[t]{4}{*}{3} & Effectivity of $W C C$ : & & \\
\hline & Imagination level & Written & $\begin{array}{l}\text { Imagination ability } \\
\text { detection test sheet }\end{array}$ \\
\hline & Conception Status & Written & $\begin{array}{c}\text { VSEPR and } \\
\text { Hybridization Test Sheet }\end{array}$ \\
\hline & Concent of $W C C$ & Written & $\begin{array}{c}\text { WCC draft on VSEPR } \\
\text { and hybridization }\end{array}$ \\
\hline
\end{tabular}

\section{Data Analysis}

WCC validity data were analyzed descriptively quantitatively and qualitatively. Quantitative descriptive analysis uses the frequently occurring score (Mo) obtained from the expert team on each developed WCC indicator. The validation score requires an understanding between the three scores obtained. This understanding can be obtained with the following percentage of agreement $(\mathrm{R})$.

$$
R=\left[1-\frac{A-B}{A+B}\right] \times 100 \%
$$

A and B are scores from each validator using a Likert scale score (see Table 2) with A being the higher score and $\mathrm{B}$ being the lowest score. Validation scores were obtained from three validators so that the percentage of each $\mathrm{R}$ was calculated, namely (R)1,2; (R)1,3; and (R)2,3. WCC validity is declared reliable if $\mathrm{R} 75 \%$ (Borich, 1994). Qualitative descriptive analysis was carried out based on corrective notes or constructive input from the expert team in order to produce a better WCC. WCC is declared to meet the requirements of construct and content validity, if each indicator has a minimum Mo of 4 (Riduwan, 2013) and there are no disagreements between validators (Borich, 1994) and there are no conceptual errors.

The data from the student response questionnaires were analyzed descriptively quantitatively and qualitatively using the Guttman scale score, then the percentage obtained can be interpreted into the criteria referred to in Table 2.

Tabel 2. Responses criteria

\begin{tabular}{cc}
\hline Percentage $(\boldsymbol{\%})$ & Criteria \\
\hline $0-20$ & Very Bad \\
$21-40$ & Poor \\
$41-60$ & Fair \\
$61-80$ & Good \\
$81-100$ & Excellent \\
\hline
\end{tabular}

(Riduwan, 2013)

Based on these criteria, WCC can be said to be practical if it gets a positive response from students on the 14 practicality indicators. That is, students who answered "Yes" $61 \%$ (Riduwan, 2013).

The test results data for detecting students' imagination abilities were obtained using an imagination test device with chemical content developed by Verawahyuni 
(2014) and analyzed with the help of SPSS for categorizing students' imagination levels. Verawahyuni classified imagination abilities, namely the group with the category of High Imagination (IT), the group with the category of Medium Imagination (IM), and the group with the category of Low Imagination (IR).

The students' conceptional status was analyzed based on the student's answer data on the VSEPR and hybridization test sheets as well as the WCC draft data (ie at the misconception validation stage, the stage of creating cognitive conflict conditions, the stage of providing assistance for the occurrence of equilibration, and the stage of reconstructing student understanding in the first part) after remedial learning in the implementation of conceptual change strategies. Analysis of students' conceptional status based on the results of the Four-tier Diagnostic Test guided by Table 3.

Table 3. Criteria for grouping student conceptions based on four-tier diagnostic test

\begin{tabular}{|c|c|c|c|c|c|}
\hline Tier 1 & Tier 2 & Tier 3 & Tier 4 & \multirow[t]{2}{*}{ Conception } & \multirow[t]{2}{*}{ Abbreviation } \\
\hline Jawaban & Confidence & Reason & Confidence & & \\
\hline False & Yes & False & Yes & Misconception & M \\
\hline False & Yes & False & No & Not & TPK \\
\hline False & No & False & Yes & Understand & \\
\hline False & No & False & No & & \\
\hline True & Yes & True & Yes & Understand & PK \\
\hline True & Yes & True & No & & \\
\hline True & No & True & Yes & & \\
\hline True & No & True & No & & \\
\hline True & Yes & False & Yes & & \\
\hline True & Yes & False & No & & \\
\hline True & No & False & Yes & Partially & PS \\
\hline True & No & False & No & Understand & \\
\hline False & Yes & True & Yes & & \\
\hline False & Yes & True & No & & \\
\hline False & No & True & Yes & & \\
\hline False & No & True & No & & \\
\hline \multicolumn{4}{|c|}{ If False one, two, three or all Not filled } & $\begin{array}{c}\text { Can Not be } \\
\text { Coded }\end{array}$ & TKD \\
\hline
\end{tabular}

(Amin et al., 2016)

Data analysis at the stage of reconstruction of students' understanding of the last part which contains questions is calculated using the formula:

$$
\Sigma \text { Score }=\text { Correct score for question no } 1+2+3+4+5+6
$$

The shift in conception status of the treatment target students was analyzed based on changes in students' conceptions seen from the initial conception status (before being treated) and the final conception status (after undergoing a conceptual change strategy which was administered in the form of a worksheet). WCC is declared effective if (1) evidence is obtained that there is a shift in the status of M, TPK, and PS to PK; and (2) there is no shift in the status of PK to M, TPK, and PS. 


\section{- RESULT AND DISCUSSION Validity of $W C C$}

The results of the validation are in the form of assessments and suggestions. Assessment is used as a validation score obtained, while suggestions are used to improve the WCC that was developed in order to produce a better WCC. Determination of validity (construction) standards with a minimum score of 4 mode and the percentage value of understanding between validators above $75 \%$, then the analysis can be given as follows. Nine indicators (learning objectives, student conception status, instructions for using worksheets, validation of misconceptions, creation of cognitive conflict conditions, providing assistance for equilibration, reconstruction of student understanding, individual character services, and general review) developed worksheets, none of the indicators received the score of the assessment with the mode below 4 . The score of mode 5 (overall on the VSEPR concept and $78 \%$ on the hybridization concept) became the majority of the validator's assessment with a very valid category. The percentage of agreement value was also not found to be below $75 \%$ in the WCC concept of VSEPR and hybridization. That is, the three validators are in the area of understanding that do not differ in providing an assessment. A validator who gives a score of 4 on an indicator can accept the decision of another validator when giving a score of 5.

In the format for assessing the validity of the WCC draft VSEPR and hybridization concepts, especially in the relevance assessment section, no validator was found who wrote or stated that: (1) the WCC draft of VSEPR and hybridization concepts contained False conceptions, (2) incompatibility of the WCC concepts of VSEPR and hybridization as means of supporting the implementation of remedial learning based on conceptual change strategies, and (3) incompatibility of WCC VSEPR concepts and hybridization which are used to facilitate the occurrence of thinking processes within limits ranging from disequilibration, re-adaptation, and equilibration as the core of the conceptual change process.

Of the three components assessed, none of them got a mode score below 4 . In fact, the mode value $5(67 \%$ on the VSEPR concept and overall on the hybridization concept) dominated the assessments of the validators in the very valid category. The percentage of agreement value was also not found to be below $75 \%$ in the WCC concept of VSEPR and hybridization. That is, the three validators are in the area of understanding that do not differ in providing an assessment. Validators who give a score of 4 on an indicator can accept the decision of another validator when giving a score of 5. This fact is evidence that the WCC draft of the VSEPR concept and the hybridization developed has met the requirements in terms of content validity (relevance).

WCC which was developed by constructs and contents is very suitable to support remedial learning as a service for students with low imagination with misconception status. However, it is still necessary to revise some parts of the WCC on the VSEPR concept and hybridization according to the advice of experts. Researchers have made improvements as suggested by the validator. Based on this, the validity requirements of the expert team against the WCC have been met.

Teaching materials (WCC) can be trusted (valid) to be used for remedial learning as a service for students with low imagination with misconception status, when the consistency (construct) and relevance (content) of teaching materials receive a very appropriate assessment from the experts. This is in accordance with the opinion of 
Plomp \& Nieveen (2010). False one criterion of a quality device is valid in terms of content and constructs.

Two WCC tools have been produced, namely: WCC for correcting misconceptions on the VSEPR concept and WCC for correcting misconceptions on hybridization concepts that meet the requirements of construct validity (consistency) and content (relevance). The next stage is implementation to evaluate its practicality and effectiveness according to the 4D design. The implementation of two WCC devices is given to the target students of class $\mathrm{X}$. This is in accordance with the formal operational stage based on the stages of cognitive development according to Piaget (there are 4 stages, namely the sensorimotor stage, pre-operational stage, concrete operational stage, and formal operational stage). The main characteristic of development at the formal operational stage is that children are able to think abstractly and logically. The abstract and logical thinking pattern used is very appropriate to accept VSEPR and hybridization materials which in fact are abstract and require good imagination. Readiness to accept abstract material is closely related to mental models (especially students can understand the concept of VSEPR and hybridization well if they have a high level of imagination). The stimulus given to increase students' imagination by providing a real picture of abstract concepts is a way to improve students' mental models.

\section{Practicality of $W C C$}

The practicality of the learning tools in this study is the practicality of the WCC when applied so that the target students can easily use it according to the wishes of the researcher. This is supported by Nieveen (1999) that the worksheet is said to be practical if the teacher and students consider the worksheet easy to use and in accordance with the plan of the researcher. The practicality of the WCC was obtained based on the student's response as the target user of the WCC to several questions posed on the student response sheet. Nieveen (1999) worksheet is said to be practical if the respondents stated that the worksheet can be used in remedial learning as indicated by the results of the student response questionnaire. The status of students who understand concepts according to scientists' concepts means that they have succeeded in reducing the misconceptions they had before through WCC. Based on the results of the student response questionnaire, it showed that students gave a positive response to the two WCCs that were developed.

Aspects of the language used in WCC, the results obtained that all students agree if the sentences or language used in WCC are easy to understand, so it does not cause double interpretation. Students also agree that the vocabulary used in WCC is easy to understand. This causes students to be able to understand all components of the WCC on the VSEPR concept and hybridization independently without the help of the teacher. Although it was found that respondents stated "unable to understand the concept of VSEPR and Hybridization independently without the help of a teacher", the number was very small, $10 \%$. This may be because students are not used to learning without explanation or instructions from the teacher. However, in the field, researchers have provided instructions (for example, students use headsets when opening animated video links) and explanations for students who do not understand individually.

Aspects of presentation, the results obtained that all students agree if the letters, numbers, and pictures that make up the WCC are clear, so as not to cause students doubt. Students also agree that the animated pictures and videos presented in WCC can help students understand the material. The animated pictures and videos on WCC are 
made as a stimulus to make it easier for students to understand the material and increase students' imagination to be able to change False conceptions. This is in accordance with what Tindall-Ford \& Sweller (2006) stated that grade 8 students accompanied by audio or visual can improve students' understanding of concepts in the learning process (Abdullah \& Johari, 2015). However, there are still 15\% of students who are not interested in the appearance of the WCC and 5\% of students are not interested in the design (cover, writing, pictures, prints, and paper quality) of the WCC. This is because students are used to LKS with cartoon designs (such as when they were in junior high school, considering that the student was just in high school, so the feel of LKS when in junior high was still carried over). Although it was found that respondents were not interested in the WCC design, none of the respondents stated that the WCC design interfered with their understanding of the material.

Aspects of the material, the results obtained that all students agree if students are more motivated to learn and find out about chemistry, and the easier it is to understand the material after being treated with WCC. Motivated students with chemistry lessons are expected to increase their understanding of concepts. This is supported by Eymur \& Omer (2016) that there is a positive relationship between learning motivation and conceptual understanding. This is evidenced by the increasing percentage of concept understanding in the direction of changes in students' conceptions before and after being treated with WCC. However, it was found that $5 \%$ of students did not agree in learning chemistry using WCC and 10\% of students did not agree if the WCC that the researcher developed could help students understand the concepts (VSEPR and Hybridization) that were taught independently. Furthermore, it is known that all students agree that WCC makes students feel that the concepts that students understand before are not quite right. That is, WCC is said to be appropriate to make students aware of the falsehood of understanding concepts in VSEPR and hybridization materials. However, it was also found that $15 \%$ of students did not succeed in changing the true concept after being treated with WCC. That is, students who have low imagination characteristics are individuals who are very difficult to change their conceptions according to scientists.

Based on the results of the calculation of the percentage of student responses to the two WCCs that were developed, it was stated that they were practical to use, the majority (above $85 \%$ ) of students using WCC gave a positive assessment of the 14 practicality indicators.

\section{Effectivity of WCC}

The effectiveness of the WCC that has been developed is a description of the remedial results that are reflected in the results of the WCC entries. WCC entries can provide an overview of the process of changing students' conceptions. Scoring of the WCC entries is not included in the assessment, but the results can be seen and analyzed as an indicator of the achievement of WCC goals in guiding students to reduce misconceptions. Before knowing the effectiveness of the WCC, the target students were determined with a test to detect students' imagination abilities and a test for understanding the VSEPR concept and hybridization of 46 students.

A total of 46 students were given an initial test (test for detecting students' imagination abilities and tests for understanding the concept of VSEPR and hybridization), obtained 20 students (class X MIPA-4 were 6 students, class X MIPA-5 was 6 students, and class X MIPA-7 was as many as 8 students) who meet the criteria, 
namely having the IT-IM-IR index with status M, TPK, PS, and PK. The 20 students are referred to as the target students of WCC users.

The WCC entry on the VSEPR concept and the WCC entry on the hybridization concept started at the initial stage of validating students' misconceptions. This stage is used to ensure that the student is suitable as the target student for WCC users. Based on the initial conception test (the results of the VSEPR concept understanding test) of the 20 target students on the VSEPR concept there were 11 students with M status, 5 students TPK, 1 student PS, and 3 PK students, while based on the initial conception test (understanding test results) hybridization concept) of the 20 target students in the hybridization concept there were 7 students with M status, 7 students in TPK, 4 students in PS, and 2 students in PK. This shows that students are suitable as target students who have the IR-IM-IT index with a load of misconceptions. However, the target students of WCC users were also carried out on students with TPK, PS, and PK statuses to determine the effectiveness of WCC.

The misconception validation stage contains several questions that lead students to express their conceptual picture of examples of T-shaped molecular geometry with VSEPR theory (WCC VSEPR concept) and examples of linear shape molecular geometry with hybridization theory (WCC hybridization concept), just to confirm students' conceptions. Based on these answers, it can be seen how students understand about examples of T-shaped molecular geometry with VSEPR theory. The initial conception status of students which was originally $M$ because of the passage of time some students ( 2 students) experienced a change in their conception status to PS, but it was not yet strong (stable), sometimes it still returned to $\mathrm{M}$ status when validated (clarification). Some of the others (3 students) have a tendency to change status to TPK and return to M status when validated. Students who were originally TPK due to the passage of time 1 student experienced a change in their conception status to PS, but it was not stable and changed to $M$ status when validated. Mostly there is a tendency to change status to M. Students who were originally PS because of the passage of time 1 student experienced a change in their conception status to TPK, but it was not stable and changed to M status when validated. Finally, students who were originally PK because of the passage of time 2 students experienced a change in their conception status to PS and 1 student became TPK, but the conception status of 3 students returned to PK when validated.

Based on students' answers about examples of linear molecular geometry with hybridization theory, it can be seen how students understand. The initial conception status of students who were originally $M$ because of the passage of time some students (1 student) experienced a change in their conception status to PS, but not yet strong (stable), sometimes still returned to $M$ status when validated (clarification). Some of the others (4 students) have a tendency to change status to TPK and return to M status when validated. Students who were originally TPK due to the passage of time 1 student experienced a change in their conception status to PS, but it was not stable and changed to $\mathrm{M}$ status when validated. Most of the time there is a tendency to change status to $\mathrm{M}$. Students who were originally PS because of the passage of time 3 students experienced a change in their conception status to TPK and then changed to $M$ status when validated. Some others have a tendency to change their status to M. Finally, students who were originally PK due to the passage of time 2 students experienced a change in their conception status to TPK and returned to PK when validated. 
The next stage is the stage of creating cognitive conflict conditions. The creation of cognitive conflicts is done by asking individuals to look at and assess animated data and videos ( $\mathrm{PCl} 3$ molecules for VSEPR concept WCC and $\mathrm{H} 2 \mathrm{~S}$ molecules for hybridization concept WCC) accompanied by true meanings and accompanied by questions to capture opportunities for confusion experienced by students. This is supported by the theory of constructivism which was born from the ideas of Piaget \& Vigotsky, both of which emphasize that cognitive change only occurs if the previously understood conceptions are processed through an imbalance process (disequilibrium) in an effort to understand new information (Nursalim, 2007). Cognitive conflict strategies are used to change cognitive understanding by giving new circumstances as external factors that are contrary to the student's cognitive structure. This research is included in the pattern of cognitive accommodation because the conceptual change process is changing the cognitive structure/scheme that the individual has. Implementation in two WCCs, this cognitive conflict is presented by providing a counter example that is in accordance with scientific rules, where it is contrary to the previous understanding of students.

Based on the results of the WCC entry, the VSEPR concept and the WCC results, the hybridization concept began to show variations in students' cognitive dissonance. Variations in cognitive dissonance are caused by the emergence of conflicts that are deliberately created at this stage. The cognition of most individuals was successfully directed and reversed by the presentation of animated data and videos ( $\mathrm{PCl} 3$ molecules for VSEPR concept WCC and H2S molecules for hybridization concept WCC) accompanied by true meanings that contradicted students' initial conceptions. Each WCC, Two students (having low level of imagination) among 20 students did not conflict when the cognitive conflict condition was created. Students who did not experience this cognitive dissonance turned out to have misconceptions at the end of the treatment. It is an important data to discuss the success and/or failure of the conceptual change strategy which is administered in the form of a worksheet. NDA and AFSA students (for WCC VSEPR concept); and BRJ and NDA students (for WCC hybridization concept) did not conflict when conditioned to conflict. These two individuals (each WCC) still had misconceptions at the end of the treatment. If discussed based on the opinion of Kang, Scharmann, \& Noh (2004), individuals who are not in conflict lack sufficient logical thinking skills, so they lack high recognition power of anomalous situations or when given new information, do not have a high interest in understanding new information, do not have high anxiety when not recognizing new information, and seem unable to reassess conflict situations or repeat searches for information that is not understood.

The next stage is the stage of providing assistance for equilibration. This stage is an advanced stage of cognitive conflict. Asking questions or providing information that leads to evidence that the new conception makes more sense than the old conception (plausible) and is more fruitful (fruitful) so that students experience equilibration, marked by starting to reject the old conception. In this stage, 18 students (for WCC VSEPR concept) among 20 students managed to understand the relationship between PEI, PEB, stick ball model, electron geometry, and molecular geometry with the help provided, while 18 students (for WCC hybridization concept) among 20 students manage to understand the connectedness of valence electrons and central atomic orbital diagrams, types of hybrids, molecular geometry, and bond formation with the help provided. 
The fourth stage in WCC is the stage of reconstructing students' understanding. The involvement of students in concept deepening exercises by answering questions and/or explaining to others, or applying new concepts they already have to explain phenomena in everyday life triggers the reconstruction of students' understanding. This stage is structured to encourage students to be willing to leave old conceptions and accept new concepts. Based on the entries at this stage, it is known that the majority of individuals achieved PK status at the end of treatment. There are six questions filled in, it is known that almost all of the target students managed to get a high score, but there were 3 students (for the WCC concept of VSEPR) and 2 students (for the WCC concept of hybridization) who answered the fields perfectly. The entries for numbers 1-6 are scored each with a maximum score of 16 so that a total score of 96 will be obtained. The following changes in the conceptions of the WCC treatment target students on the VSEPR and hybridization concepts are presented in Table 4.

Table 4. Changes in the conception of students targeted for WCC treatment on the VSEPR and hybridization concepts

\begin{tabular}{|c|c|c|c|c|c|c|}
\hline \multirow[t]{3}{*}{ Name } & \multicolumn{2}{|c|}{$\begin{array}{c}\text { WCC for VSEPR } \\
\text { Concept }\end{array}$} & \multirow[t]{3}{*}{$\begin{array}{c}\text { Change } \\
\text { Direction }\end{array}$} & \multirow{2}{*}{\multicolumn{2}{|c|}{$\begin{array}{c}\begin{array}{c}\text { WCC for } \\
\text { Hybridization } \\
\text { Concept }\end{array} \\
\text { Status Konsepsi }\end{array}$}} & \multirow[t]{3}{*}{$\begin{array}{c}\text { Change } \\
\text { Direction }\end{array}$} \\
\hline & \multicolumn{2}{|c|}{ Status Konsepsi } & & & & \\
\hline & Awal & Akhir & & Awal & Akhir & \\
\hline ARF & $\overline{\text { TPK }}$ & $\overline{\mathrm{PK}}$ & + & $\bar{M}$ & PK & + \\
\hline AFK & $\mathrm{M}$ & PK & + & $\mathrm{M}$ & PK & + \\
\hline AMR & PK & PK & 0 & PS & PK & + \\
\hline ANR & M & PK & + & TPK & PK & + \\
\hline $\mathrm{AB}$ & TPK & PK & + & TPK & PK & + \\
\hline BRJ & TPK & PK & + & $\mathrm{M}$ & M & 0 \\
\hline MFA & M & PK & + & M & PK & + \\
\hline MNF & M & PK & + & PK & PK & 0 \\
\hline NDA & M & $\mathrm{M}$ & 0 & M & $\mathrm{M}$ & 0 \\
\hline NLF & TPK & PK & + & PS & PK & + \\
\hline SK & PS & PK & + & TPK & PK & + \\
\hline UHT & M & PK & + & TPK & PK & + \\
\hline MSAP & PK & PK & 0 & M & PK & + \\
\hline AFN & M & PK & + & PS & PK & + \\
\hline AFSA & M & M & 0 & TPK & PK & + \\
\hline AN & M & PK & + & PK & PK & 0 \\
\hline DZN & M & PK & + & M & PK & + \\
\hline GMP & M & PK & + & TPK & PK & + \\
\hline LF & TPK & PK & + & TPK & PK & + \\
\hline MAS & PK & PK & 0 & PS & $\mathrm{PK}$ & + \\
\hline
\end{tabular}

Notes:

$\mathbf{M}=$ Misconception $\mathbf{T P K}=$ Not Understand $\mathbf{P S}=$ Partial Understand $\mathbf{P K}=$ Understand

Based on Table 6 , it can be seen that the students' conceptual changes were seen from the initial conception status (before treatment) and the final conception status (after undergoing the conceptual change strategy which was administered in the form of a worksheet). Based on the data in Table 6 on the WCC concept of VSEPR and 
hybridization respectively, there were 9 out of $11(81.81 \%)$ and 5 of $7(71.43 \%)$ students shifted their conception status from M to PK; 5 (100\%) and 7 (100\%) students shifted their conception status from TPK to PK; 1 (100\%) and 4 (100\%) students shifted their conception status from PS to PK.

Finally, 3 students (with WCC VSEPR concept) and 2 students (with WCC hybridization concept) treatment targets with PK status (100\%) did not experience any change in their conception status after being treated with a conceptual change strategy which was administered in the form of a worksheet. This shows that WCC on the VSEPR concept and WCC on the hybridization concept developed did not have a negative impact. This means that the two WCCs did not change the conception that was True or PK (the initial concept that students had) into M. Two WCCs could be declared effective because the majority (90\% each) of the students had successfully changed their conception through the stages of the conceptual change strategy which was administered in the form of a worksheet.

There were 2 students (10\%) who did not experience a change in their conception status even though they had been treated with a conceptual change strategy which was administered in the form of a worksheet, namely NDA and AFSA students (for WCC VSEPR concept); and BRJ and NDA students (for WCC hybridization concept). These two students (each WCC) experienced resistant misconceptions. That is, the treatment with a conceptual change strategy that is administered in the form of a worksheet does not succeed in changing (destroying) the schema that has been built up in his brain. This shows that the effectiveness of the two WCCs developed has not been perfect in removing students' misconceptions. The fact above can be discussed as False, basing it on the statement of Queloz, Schar, Wallny, Bonaccorso, \& Schmidt (2015) which explains that the condition of misconceptions in an individual's cognitive structure is more difficult to change than the condition of not understanding the concept or understanding partly.

The example of one student's False answer, for example, is an AFSA student in the WCC entry, the VSEPR concept is presented as follows. At the stage of validation of misconceptions: students answered by marking check (check list) in the True box which contained that students agreed with the example of T-shaped molecular geometry written by Kenzi which stated that the $\mathrm{PCl} 3$ molecule is False, one example of a compound that has a T-shaped molecular geometry. The answer was followed with confidence. Next, the students answered by marking tanda (check list) in the True box which contained that the students agreed with the reasons for the answer written by Kenzi which stated that the distribution of electrons from the central atom $\mathrm{P}$ in $\mathrm{PCl} 3$ has a tetrahedral electron geometry with 3 positions filled with $\mathrm{Cl}$ atoms. and one position is occupied by a lone pair of electrons, so the geometry of the PCl3 molecule is T-shaped. This reasoning is followed with confidence. Based on these answers, AFSA students are declared at status $\mathrm{M}$.

While an example of a False answer for one student, for example, is an NDA student in the WCC entry, the hybridization concept is presented as follows. At the misconception validation stage: students answered by giving a memberikan (check list) in the True box which contained that students agreed with the example of linear molecular geometry written by Fauzan which stated that the H2S molecule is False, an example of a compound that has a linear molecular geometry. The answer was followed with confidence. Next, the students answered by giving a (check list) in the True box which contained that the student agreed with the reasons for the answer written by 
Fauzan which stated that the $\mathrm{S}$ atom is the central atom, then the electron configuration is ${ }_{16} \mathrm{~S}=1 \mathrm{~s}^{2} 2 \mathrm{~s}^{2} 2 \mathrm{p}^{6} 3 \mathrm{~s}^{2} 3 \mathrm{p}^{4}$

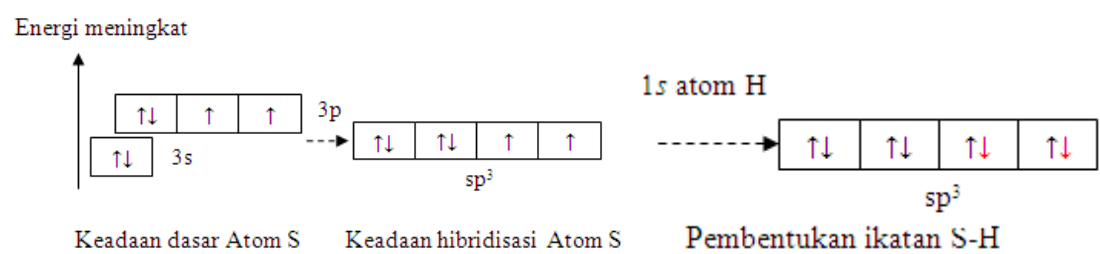

Figure 1. Electron configuration for ${ }_{16} \mathrm{~S}$ atom

The $\mathrm{sp}^{3}$ hybridization has a tetrahedral electron geometry with 2 unused electron pairs bonded to other atoms, so the molecular geometry is linear with a bond angle of $180^{\circ}$. Each $\mathrm{S}-\mathrm{H}$ bond is formed by overlapping the sp3 hybrid orbital of the $\mathrm{S}$ atom with the 1s orbital of the $\mathrm{H}$ atom. This reasoning is followed with confidence. Based on these answers, NDA students are declared at status M.

\section{- CONCLUSION}

The two WCCs developed have been declared feasible (valid, practical, and effective) to be used as learning devices in an effort to reduce misconceptions about the VSEPR concept and hybridization for students with low imagination abilities. It was found that one and three students using WCC stated that it was impractical in the first and second WCC, although it did not invalidate the fulfillment of practicality requirements, it was necessary to consider efforts to improve the second WCC before entering the dissemination stage.

\section{- REFERENCES}

Abdullah, N., \& Johari, S. (2015). The existence of alternative framework in students' scientific imagination on the concept of matter at submicroscopic level: macro imagination. Journal of Education and Practice, 6(21), 55-64.

Agiande, D. U., James, J. W., Albert, Y. D., \& Danbiyu, P. T. (2015). Conceptual change theory as a teaching strategy in environmental education. European Scientific Journal, 11(35), 395-408

Amin, N., Wiendartun., \& Samsudin, A. (2016). Analisis instrumen tes diagnostik dynamic-fluid conceptual change inventory (DFCCI) bentuk four-tier test pada beberapa SMA di Bandung Raya. Simposium Nasional Inovasi dan Pembelajaran Sains (SNIPS) (pp 570-574).

Ardi, W. S., Hayuni, R. W., \& Mahmudi. (2014). Analisis pemahaman konsep siswa kelas xi ipa sman 1 malang pada topik bentuk molekul [Analysis of the understanding of the concepts of students in class xi ipa sman 1 Malang on the topic of molecular shapes]. Jurnal Zarah, 2(1).

A Refresh-Teaching 2015: Misconceptions. Retreived 01 September, 2018 from http://blogs.ethz.ch/refreshteaching/files/2015/01/RefreshTeaching_Misconceptio ns LET.pdf

Borich, Garry. (1994). Observation Skill for Effective Teaching. New York: Mac Millan Publishing Company.

Chiu, M. H. (2005). A national survey of student's conceptions in chemistry in taiwan. Chemical Education International, 6(1): 1-8. 
Eymur, G. \& Omer, G. (2016). The collaboration of cooperative learning and conceptual change: Enhancing the students' understanding of chemical bonding concepts. Int J of Sci and Math Educ, 15(5).

Hegarty. M. (2012). Spatial thinking across the colleg curriculum. Final Report. University of California.

Improving Imagination Skills In Order To Assist Abstractive Learning. Retreived 01 September, 2018 From http://hdl.voced.edu.au/10707/252114

Kang, S., Scharmann, L. C., \& Noh, T. (2004). Reexamining the role of cognitive conflict in science concept learning. Research in Science Education, 34(1), 71-96.

Laliyo, L. A. R. (2011). Model mental siswa dalam memahami perubahan wujud zat [Students' mental models in understanding changes in the form of substances]. Jurnal Penelitian dan Pendidikan, 8(1), 1-12.

Majid, Abdul. (2018). Reduksi beban miskonsepsi mahasiswa calon guru kimia berbasis gaya belajar, model mental, dan tingkat konflik kognitif menggunakan strategi conceptual change berbantuan integrated worksheet (Disertasi tidak dipublikasikan). Pendidikan Sains, Pascasarjana, Universitas Negeri Surabaya.

Miskonsepsi dan Perubahan Konsep dalam Pendidikan Fisika. Retreived 01 September 2018 from https://books.google.co.id/books?hl=en\&lr=\&id=sFJJDwAAQBAJ\&oi=fnd\&pg= $\underline{\text { PP1\&dq=ebook+tentang }+ \text { miskonsepsi }+ \text { dan+perubahan+konsep+pendidikan+kimi }}$ a\&ots=EzYOpGM0ae\&sig=hKg2fewDC6VYn1LCTNUEXuR6vg\&redir_esc=y\#v=onepage \&q=ebook\%20tentang\% 20miskonsepsi\%20dan\%20perubahan\%20konsep\%20pendidikan\%20kimia\&f=fal $\underline{\mathrm{se}}$

Nieveen, N. (1999). Prototype to reach product quality. In Van den Akker, J. (2006). Approaches and tools in educational and training. Dordrect: Kluwer Academic Publisher.

Nursalim, M. (2007). Psikologi pendidikan [Educational psychology]. Surabaya: Unesa University Press.

Ozmen, H. (2004). Some student misconceptions in chemistry: A literature review of chemical bonding. Journal of Science Education and Technology, 13(2), 147-159.

Perez, J. R., Ballester, P., Calatayud, M. L., Garcia, L., Sabater, M., \& Trilles, G. (2017). Student's misconceptions on chemical bonding: A comparative study between high school and first year university students. Asian Journal of Education and e-Learning, 5(1), 1-15.

Plomp, Tjeerd. (2010). Educational Design Research: An Introduction Tjeerd Plomp dan Nienke Nieeven (Ed.). An Introduction to Educational Design Research. Enschade: SLO. Netherlands Institute for Curriculum Development.

Riduwan. (2013). Skala pengukuran variabel-variabel penelitian [Measurement scale of research variables]. Bandung: Alfabeta.

Suyono, Masriyah, \& Muchlis. (2016). Preparasi sarjana pendidikan kimia tanpa miskonsepsi di FMIPA Unesa [Preparation of undergraduate chemistry education without misconceptions at FMIPA Unesa] (Laporan Hasil Penelitian Unggulan Perguruan Tinggi yang tidak dipublikasikan), Lembaga Penelitian, Surabaya.

Tasker, R \& Rebecca, D. (2006). Research into practice: visualisation of the molecular world using animations. Chemistry Education Research and Practice, 7(2), 141159. 
Thiagarajan, S., Semmel, D. S., \& Semmel, M. I. (1974). Instructional development for training teachers of expectional children. Minneapolis, Minnesota: Leadership Training Institute Special Education, University of Minnesota.

Uyulgan, M. A. \& Nalan, A. (2016). An insight towards conceptual understanding: looking into the molecular structures of compounds. Acta Didactica Napocensia, 9(4), 49-70.

Uyulgan, M. A., Nalan, A., \& Senol, A. (2014). Assessing the students' understanding related to molecular geometry using a two-tier diagnostic test. Journal of Baltic Science Education, 13(6), 839-855.

Verawahyuni, Helda. (2014). Pengembangan instrumen pendeteksi penyebab miskonsepsi kimia berbasis model mental pada konsep struktur atom (Tesis tidak dipublikasikan). Pendidikan Sains, Pascasarjana, Universitas Negeri Surabaya.

Yayla, R. G. \& Gulseda, E. (2011). Mental models of pre-service science teachers about basic concepts in chemistry. Western Anatolia Journal of Education Science, 285294. 